\title{
Religion in census, the 2011 Albania experience and its flaws
}

Ilir Akshija, PhD.

University of Medicine Hospital Center, Albania

\section{Abstract}

The sensitive topic of religion in the Albanian 2011 census and the coming one is the focus of this study. The country majority is composed of ethnic Albanians, sharing the same nationality; blood, language, culture, territory while religion differs. It was found a flaw in categorization under the category 'Bektashi', one of the Albanian traditional divisions historically a sub-category of 'Islam'. Placing it as a separate category, while the main body category 'Islam' is the other option creates fogginess for the inquired person. Checking on 'Islam' excludes s/he from the possibility to choose 'Bektashi' and vice versa. Data retrieved from the official INSTAT Albania online web atlas and reorganized second study objectives. Maps show a shift from traditional religious categories, Muslim, Catholic, Orthodox and Bektashi with clear geographical connotations. Traditional religious nominations range from the lowest loss of $2.9 \%$ to $56.5 \%$. With a range $53.6 \%$, and mean and standard deviation $23.6 \pm 13.3 \%$, change is statistically significant $p<0.001$. The whole country records a fidelity to traditional categories of $75.6 \%$. The quest of separation from the main body of a religious affiliation is a special case of separation because the sub-division always pretends to save the original message, not bringing a novelty. The case of the Albanian religious census categories superposition constitutes a technical error that needs revision.

Keywords: Census 2011; Albania; religion; Islam; Muslim; Bektashi; political; ethnic.

\section{Introduction}

Studying religion demographics of any Balkan state needs to take in consideration nationality. Both variables are strong identifiers of these populations and historical events created interpositions originating from geographic and national frontiers as much as artificial ones coming on effect from short sighted political vision of the great powers. How much entangled this affairs are, can be easily traced even in premodern European politics. A common occurrence in power transition from prince to prince in a small region as Montenegro was subject to the scrutinization and intervention of many interested powers. In year 1851, the successor in power, accepts the ascension to throne refusing to be part of the holy orders leaving the duty to the Bishop. He had to get permission from Russia to marry a lady of Austrian origins, even being an Austrian Slav because of the tug between Austria and Russia. The Sultan attacked Montenegro because he recognized only the rule of the Bishop and not a hereditary prince. 
The Prince was saved from Austrian and Russian diplomatic intervention. [1] In the words of the seventeenth ottoman traveler Evliya Çelebi, Shkodra fortress was conquered from Sultan Mehmed the Conqueror in year 1478. Inside the fortress there were 100 garrison soldiers houses and in the open town 1800 stonework houses and 500 shops. He considers all city population as Muslims. [2] Shkodra is the neighboring Albanian district to Montenegro, contested many times and fought for centuries. The region is subject to diverse nationalities and Albanians are surrounded by Slavs, Greeks, Turks, Bulgarians and Adriatic Sea separates them with Italians. Historically pagan beliefs were followed with the presence and authority of Christian Catholics and Orthodox, Muslims and lately of atheists and other religious affiliations. Neither religion nor nationalities are dichotomous variables in the Balkan region. Adding the pragmatic character of a part of humans any analysis remains fragile in authority. [3]

More than in other regions in Balkans statistics are used for nationalist agendas and distorted to unacceptable dimensions. The famous 'Enquête dans les Balkans' published in 1914 from Carnegie Endowment calls those statistics exaggerated and considers impossible to refer to a reliable population count. For example the Bulgarian statistics on North Makedonia, (M. Kantchov, 1900) counts 1,181,336 Bulgars, 228,702 Greeks and 700 Serbs, while the Serbian statistics (M. Gopcevic, 1889) count 2,048,320 Serbs, 57,600 Bulgars and 201,140 Greeks. Greek statistics follow the general rule of the time, (M. Dèlyani, 1904) counting 332,162 Bulgars, 652,795 Greeks and no data about Serbs. [4] Then, schisms are a practical thing and Albania is a frontier. Both Roman Catholic and Eastern Orthodox communities are found in Albania. The schism inculcates around 900s and finalizes as the Great Schism during the Florence's' (1439) council. [5] The other famous schism is the Islamic Schism, the Sunni and Shia divide. No major groups of Shia Muslims existed in Albania. The traditional Islam was represented from Sunni groups and the respective Sufi brotherhoods. Sufis are practitioners of Tasawuf entitled from orientalist researchers as Islamic mysticism. Originally all Sufi orders are Sunni Muslims.

To make more complex the situation the communist regime in 1967 forbids all religious practices. Properties are confiscated and believers persecuted. The dictator declares the first atheist country in human history. Article 55 of the 1976 constitution, lists the creation of religious organizations next to antidemocratic, antisocialist and fascist organization. [6] Although some of the population could have supported the decision facts on religious affiliation after the fall of communism clearly show the outrage of a minority to a whole population. The falsification of data in this case is unprecedented. The slogans of that time spoke of a whole atheist population and some elders with backward ideas. Year 1991 brought the fall of the atheist regime and the liberty of belief and religious practices. But counting religion affiliation can't be done successfully without taking in consideration history. Actually Albanians fit very 
well the definition of nationality; blood, language, culture, territory are common for them, while religion and state borders don't. Referring to CIA World Factbook; 82.6\% of Albania is composed of the Albanian ethnic group, while they make $92.9 \%$ of Kosovo population, 4.9\% of Montenegro and 25.1\% of North Macedonia. In year 2019, 1.2 million Albanian citizens lived as emigrants. [7] The table following (Table 1) represents the percentage distribution of religious or none's of Albania and neighboring countries populated with ethnic Albanians. [8] The presented estimates have to be scrutinized carefully as overlapping categories can be found or more than one entity is enclosed in on category as the case of nomination 'Catholic' which includes the Roman Catholics of Albania and Kosovo, Catholics of Montenegro and Christians in North Macedonia.

\begin{tabular}{|l|r|r|r|r|r|r|r|}
\hline & Muslim & Catholic & Orthodox & Bektashi & other & unspecified & Atheists \\
\hline Albania & $56.70 \%$ & $10.0 \%$ & $6.80 \%$ & $2.10 \%$ & $5.7 \%$ & $16.2 \%$ & $2.5 \%$ \\
\hline Kosovo & $95.60 \%$ & $2.2 \%$ & $1.5 \%$ & $0.0 \%$ & $0.1 \%$ & $0.6 \%$ & $0.0 \%$ \\
\hline Montenegro & $19.10 \%$ & $3.4 \%$ & $72.1 \%$ & $0.0 \%$ & $1.5 \%$ & $2.6 \%$ & $1.2 \%$ \\
\hline N. Macedonia & $33.30 \%$ & $0.4 \%$ & $64.8 \%$ & $0.0 \%$ & $0.0 \%$ & $1.5 \%$ & $0.0 \%$ \\
\hline Greece & $2.00 \%$ & $0.0 \%$ & $81-90 \%$ & $0.0 \%$ & $3.0 \%$ & $1.0 \%$ & $4-15 \%$ \\
\hline
\end{tabular}

Table 1. Data on religion as percent of total, Albania and bordering countries The World Factbook - Central Intelligence Agency, 2020

\section{A comparison with the past}

Data (Table 1) are estimates of 2002 to 2011. Data on Albania come from Census 2011 and as can be seen the category 'unspecified' is the largest compared to other countries. Atheists comprise $2.5 \%$ of the answers and $16.2 \%$ which are considered unspecified fall in sub-categories of mostly refuting to answer, $13.8 \%$. Believers without denomination results $5.5 \%$. 'Why these sub-groups are so large?' - is an evitable question. Both categories are large compared to neighboring countries. The answer has to go back in time before questioning the Census 2011 methodology, data collection and manipulation. Fortunately, data on Census 1923 (Table 2) can be found and compared with the latest data. In year 1923 all residents are categorized as Muslim, Orthodox or Catholic. The last census necessitates adding a new category, 'other' which includes $26.5 \%$ of the residents. We don't know if other significant categories were undercounted in 1923 and some doubts remain as the original author T. Selenica speaks of possible flaws in counting and response. The atheist phenomenon could have been present but it gained significant dimension after WWII and is still present. New religious beliefs have contributed but the most significant part is the believers without a denomination. The category is quite new and is interpreted as believing in God but not adhering to a specific religious formal body. Of major concern is the group 
refuting to answer which arises the questions on Census methodology. For example in 1923 Census the Bektashi order it was included in the nomination 'Muslim' while for comparison purposes as in 2011 it was a specific category is included (Table 2) at the group 'other'. Tracing 1936 fonts of the religious journal Zani i Naltë declarations of Bektashi leaders posit their order as pure Islam. [9] Census 2011 creates a new category 'Bektashi', formerly categorized under 'Muslim'. No declaration can be found that the order left Islam, nor a respondent can chose more than a category, as basic statistics requires the elements of a group to be exclusive to a category and all of them to be exhaustive. Here is found a possible flaw in methodology. Christians can find other flaws as they pretended but at least they could chose between nominations 'Orthodox' and 'Catholic'. Discriminating, if this was a point of view or a conceptual error has to be scrutinized.

\begin{tabular}{|l|r|r|r|r|}
\hline & \multicolumn{2}{|c|}{1923} & \multicolumn{2}{|c|}{2011} \\
\hline Religion & Resident population & $\begin{array}{r}\text { Resident population } \\
\text { (\%) }\end{array}$ & Resident population & $\begin{array}{r}\text { Resident population } \\
\text { (\%) }\end{array}$ \\
\hline Muslim & 558,275 & 68.6 & $1,587,608$ & 56.7 \\
\hline Orthodox & 171,185 & 21.0 & 280,921 & 10.0 \\
\hline Catholic & 84,862 & 10.4 & 188,992 & 6.7 \\
\hline Other & 0 & 0.0 & 742,617 & 26.5 \\
\hline Total & 814,322 & 100.0 & $2,800,138$ & 100.0 \\
\hline
\end{tabular}

Table 2. Distribution of religion, Albanian resident respondent population census 1923 and 2011 [10] [11]

\section{Census 2011 on religion}

The major finding in the 2011 religion census is the shift from the census of 1923. Albania INSTAT Web Atlas makes possible to retrieve data online, otherwise not possible to reach formally, second administrative divisions. After retrieving data on administrative divisions 'prefectures' and ' 61 local units' a new variable was created containing traditional nomination of religious groups, Muslim, Bektshi, Catholic and Orthodox with the goal to evaluate the geographical distribution of the shift. To make regions of differing population size comparable values were transformed in percentages. An example (Table 3 ) of this distribution representing traditional nominations and their total value as totals percentage shows large differences through regions. Maps' footnote (Figure 1) shows all the calculations and their representation on the map. 


\begin{tabular}{|l|r|r|r|r|r|}
\hline Prefecture (local unit) & \multicolumn{1}{|c|}{$\begin{array}{c}\text { Islam } \\
\text { (\%) }\end{array}$} & $\begin{array}{c}\text { Bektashi } \\
\text { (\%) }\end{array}$ & $\begin{array}{c}\text { Catholic } \\
\text { (\%) }\end{array}$ & $\begin{array}{c}\text { Orthodox } \\
\text { (\%) }\end{array}$ & $\begin{array}{c}\text { Total } \\
\text { (\%) }\end{array}$ \\
\hline Shkodër (Shkodër) & 52.3 & 0.1 & 38.6 & 0.5 & 91.5 \\
\hline Lezhë (Mirditë) & 2.1 & 0.0 & 92.8 & 0.1 & 95 \\
\hline Dibër (Peshkopi) & 94.6 & 0.0 & 0.2 & 0.1 & 94.9 \\
\hline Tiranë (Tiranë) & 55.7 & 3.4 & 5.4 & 6.4 & 70.9 \\
\hline Berat (Berat) & 55.5 & 2.5 & 1.1 & 8.0 & 67.1 \\
\hline Korçë (Korçë) & 46.9 & 2.2 & 1.4 & 28.2 & 78.7 \\
\hline Vlorë (Vlorë) & 43.3 & 0.8 & 1.4 & 9.1 & 54.6 \\
\hline Gjirokastër (Gjirokastër) & 42.3 & 5.3 & 2.8 & 14.6 & 62.5 \\
\hline
\end{tabular}

Table 3. Distribution in as percentage of some local units for the four traditional religious categories, Census 2011

The summing up of traditional categories of religious affiliation shows wide variation through local units, for example in Shkodër (Shkodër) 91.3\% of the interviewed falls in one of the above categories while Vlorë (Vlorë) only $54.6 \%$. The lowest finding, $43.5 \%$ is in the local unit of Gramsh, Elbasan prefecture. The results are mapped (Figure 1) where each change in color represents a category (in percent), and the intensity represents a $10 \%$ change of the cumulative total of the traditional categories; Islam, Bektashi, Catholic, Orthodox. The darkest area is the local unit of Gramsh, Elbasan prefecture as it has a fall in representation to the category 6 [50-40.1\%]. 


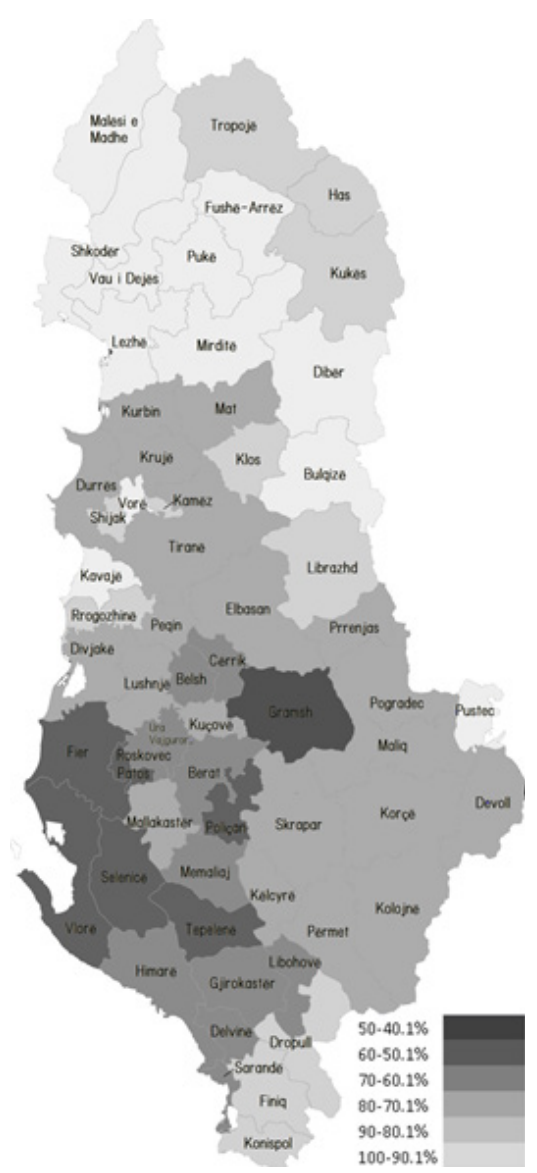

Figure 1. Distribution second local units, total of major religious traditional categories; Islam, Bektashi, Catholic, Orthodox, as percent of total respondents, Census 2011.

* Korçë (Pustec - 97.1\%), Shkodër (Vau i Dejës - 95.2\%), Lezhë (Mirditë - 95.0\%), Dibër (Dibër - 94.9\%), Shkodër (Malësi e Madhe - 93.9\%), Shkodër (Pukë - 93.1\%), Shkodër (Fushë-Arrëz - 92.9\%), Dibër (Bulqizë - 92.3\%), Tiranë (Kavajë - 92.0\%), Shkodër (Shkodër - 91.3\%), Tiranë (Vorë - 91.2\%), Lezhë (Lezhë - 90.9\%), Vlorë (Konispol - 89.7\%), Tiranë (Rrogozhinë - 89.6\%), Kukës (Kukës - 89.0\%), Gjirokastër (Dropull - 88.0\%), Dibër (Klos - 87.7\%), Durrës (Shijak - 86.6\%), Tiranë (Kamëz - 85.7\%), Vlorë (Finiq 84.4\%), Elbasan (Librazhd - 84.4\%), Kukës (Tropojë - 83.2\%), Kukës (Has - 83.1\%), Lezhë (Kurbin - 79.4\%), Fier (Divjakë - 79.4\%), Korçë (Devoll - 79.3\%), Durrës (Durrës - 79.2\%), Elbasan (Prrenjas - 78.9\%), Korçë (Korçë - 78.7\%), Durrës (Krujë - 78.0\%), Korçë (Pogradec - 78.0\%), Korçë (Maliq - 77.5\%), Elbasan (Peqin - 76.1\%), Gjirokastër (Përmet - 75.3\%), Korçë (Kolonjë - 75.2\%), Fier (Mallakastër - 73.6\%), Elbasan (Elbasan - 73.5\%), Dibër (Mat - 72.4\%), Fier (Lushnje - 72.3\%), Berat (Kuçovë - 72.1\%), Tiranë (Tiranë - 70.9\%), Berat (Skrapar - 70.9\%), Gjirokastër (Këlcyrë - 70.9\%), Gjirokastër (Libohovë - 68.1\%), Berat (Berat - 67.1\%), Vlorë (Delvinë - 65.7\%), Vlorë (Himarë - 65.4\%), Gjirokastër (Gjirokastër - 65.0\%), Fier (Roskovec-64.9\%), Elbasan (Belsh - 64.6\%), Berat (Ura Vajgurore - 64.3\%), Elbasan (Cërrik - 61.0\%), Gjirokastër (Memaliaj - 61.0\%), Vlorë (Sarandë - 60.2\%), Fier (Fier - 57.1\%), Gjirokastër (Tepelenë $55.5 \%)$, Berat (Poliçan - 54.8\%), Vlorë (Vlorë - 54.6\%), Fier (Patos - 51.8\%), Vlorë (Selenicë - 51.0\%), Elbasan (Gramsh - 43.5\%), Shqipëria (in total) $-75.6 \%$. 
The same data are plotted as a stacked graph. Positive values are the cumulative traditional religious affiliation (Islam, Bektashi, Catholic, Orthodox, as percent of total respondents, Census 2011) percentages for each local unit and negative values represent the same local unit actual percent shift from the total, where shift is considered change from the 1923 census, where traditional categories make $100 \%$ of total.

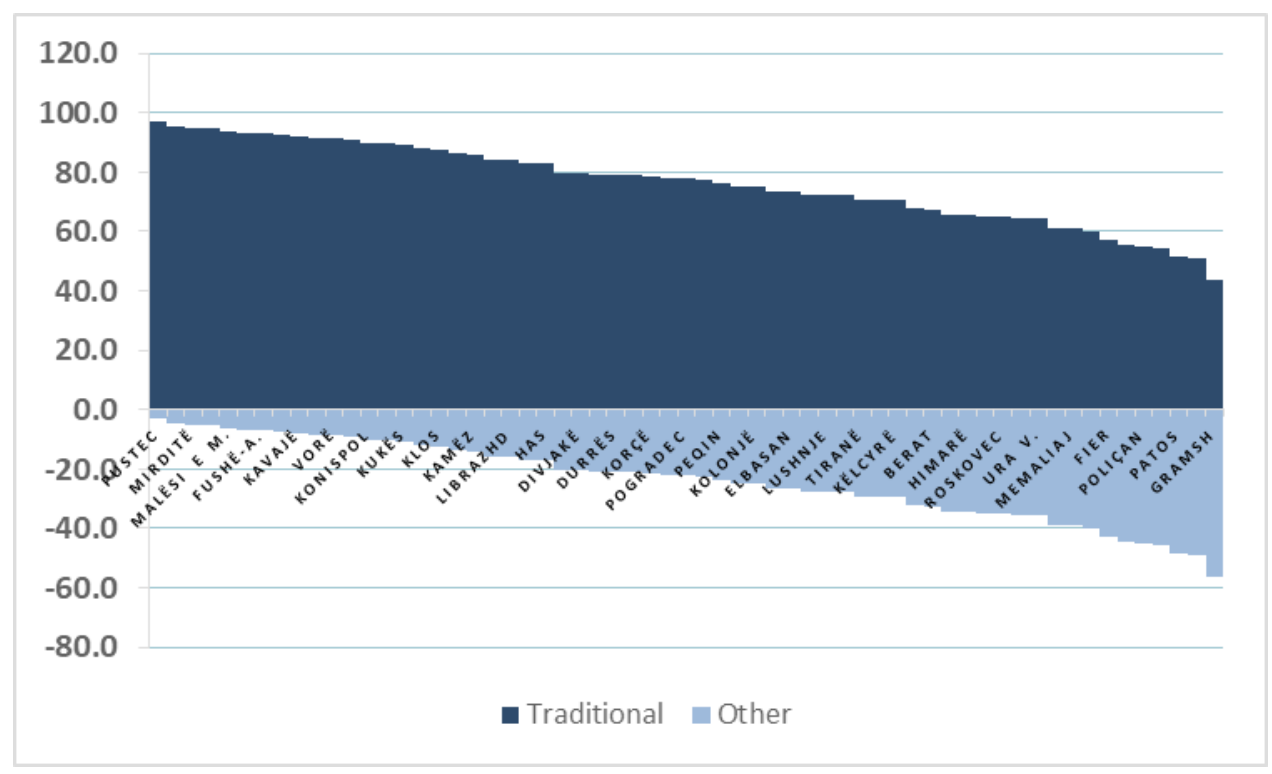

Figure. 2 Stacked 100\% local units 'major religious traditional categories' and 'other'

The situation of the four traditional categories; Islam, Bektashi, Catholic, Orthodox records the lowest loss in the local unit of Korçë (Pustec - 2.9\%), and the largest one in Elbasan (Gramsh - 56.5\%), with a range 53.6\%, and mean and standard deviation $23.6 \pm 13.3 \%$. The change is statistically significant $p<0.001$. The whole country records a fidelity to traditional categories of $75.6 \%$.

Following is the table (Table 4) resuming the categories of Muslims in percentage second prefecture, the major administrative division in Albania, as represented in Census 2011. Both categories nominate themselves as Muslims, while paradoxically census records them in the following categories. Distribution varies second geographical position showing the majority of the category 'Bektashi' located in the south of the country. 


\begin{tabular}{|l|r|r|r|r|r|}
\hline Prefecture & \multicolumn{1}{l|}{ Population } & \multicolumn{1}{l|}{ Islam \%* } & \multicolumn{1}{l|}{ Islam ** } & \multicolumn{1}{l|}{ lektashi \%* } & \multicolumn{1}{l|}{ Bektashi** } \\
\hline Shkodër & 215347 & 44.8 & 96475 & 0.1 & 215 \\
\hline Kukës & 85292 & 83.8 & 71475 & 0.0 & 0.0 \\
\hline Dibër & 137047 & 81.4 & 111556 & 3.8 & 5208 \\
\hline Lezhë & 134027 & 14.8 & 19836 & 0.1 & 134 \\
\hline Tiranë & 749365 & 62.3 & 466854 & 2.7 & 20233 \\
\hline Durrës & 262785 & 67.5 & 177380 & 1.6 & 4205 \\
\hline Elbasan & 295827 & 64.4 & 190513 & 0.5 & 1479 \\
\hline Fier & 310331 & 48.5 & 150511 & 1.0 & 3103 \\
\hline Berat & 141944 & 50.2 & 71256 & 8.2 & 11639 \\
\hline Korçë & 220357 & 59.0 & 130011 & 2.1 & 4627 \\
\hline Gjirokastër & 72176 & 38.5 & 27788 & 8.5 & 6135 \\
\hline Vlorë & 175640 & 42.1 & 73944 & 1.1 & 1932 \\
\hline Total & $\mathbf{2 8 0 0 1 3 8}$ & $\mathbf{5 6 . 7}$ & $\mathbf{1 5 8 7 5 9 9}$ & $\mathbf{2 . 1}$ & $\mathbf{5 8 9 1 1}$ \\
\hline
\end{tabular}

Table 4. Distribution by prefectures, frequency and percentage of categories 'Islam' 'Bektashi', Census 2011

\section{Finding the approach}

The placement of the religious affiliation question in the 2020 Census in Albania at the non-core topic category makes obligatory to start the approach not from religion but census. [12] Census as a political process has to be the point of starting when analyzing approaches to topics. [12] This is census primary function and a non-core topic such as religion when faced with question conception, data gathering and analysis remains a function of a political process while it in itself originates from personal beliefs although externalized as a simple word of mouth declaration or a full range behavior consisting in specific religious practices. The religious approach towards religion affiliation in censuses is largely variable. One model of conceptualization would define religion as legal membership, as descent, as motive of behavior and as belief. [14] The Albanian model would include the religion as a legal membership during the ottoman period combined to belief. Christians were under different bonds of taxation and military service compared to Muslims. This model has changed and the actual one places all religious affiliations on the same status. The discussion is shifted from discrimination between religions to religion and state. Western models are simpler to explain because of legal regulations in concomitance with historical roots of democracy and free speech. Albania can hold in legal regulations but the democracy is quite new and approaches to religion can't totally escape former communist patterns. [15]

\footnotetext{
* retrieved from 'Instat - Web Atlas'.

** Calculated based form the 'Instat - Web Atlas' percentage and population by prefecture from Census 2011.
} 
A Bayesian approach would take in consideration the distribution of religious preferences and political affiliation to the conception of the religious question in census. Germany considers itself not a secular [laizistischer] state but included the question or religion in its census. Italy, the center of Catholicism and predominantly a catholic one but a secular state, posed as Italian laicità, doesn't include it. [16] This examples show that the topic is complex and while put in the non-core topics its formulation requires professionalism and caution. For example Italy it's not indifferent toward counting religion, ISTAT monthly registers marriages second religious or civil rites. [17] Further studies were done on affiliation and religious practices comparing religious beliefs to the nationality of the immigrant population. [18] The same can be found in countries that don't include religion in census. For example one survey in USA, 1957 published the cross-tabulation of children ever born per 1,000 women with religion. [19] The other experiences come from the communist camp which is more common to Albanian practices. The soviet censuses brought problems of under-numeration from fear of declaring religion or not showing results similar to state propaganda. When less than half of the population 16 years and older identified themselves atheists directors' census Kvitkin and Kraval were executed. The following Russian census of 2002 still carried gross misconceptions between counting religion as ethnicity. [20]

Politics, ethnicity and religion mix especially in countries where manipulation is possible or a goal in itself. Ethnicity in Albania is out of the discussion, while politics divides the small country. Northern part of the country composed more of Muslim and Catholic communities traditionally were anticommunist still choosing to be strongholds of the right political parties, while south composed of Muslim, Orthodox and Bektashi incline to the left. Overrepresented during communist rule the leftist technical bureaucrats of a certain age are the actual decision makers. Their behavior has to be modified from democratic participation in technical processes regulation. This is not a question of personal belief as differences in approach result between age groups, economic and educational categories. [21] For example 'nones' in USA 2008, people who do not identify with any religious group, are found to be younger than the rest of the population. [22] Also education is an important discriminator. The number of scientist is found to be 52 percent as not having a religious affiliation compared to 14 percent of the entire population. [23] This data however have to be taken in consideration carefully as they can change overtime. For example the old 1851 English census data show the 'labouring' classes as estranged from religious bodies and the majority of absentees. [24] Results which need careful evaluation first from biases caused by the time of census technical deficiencies and today's probable change of class's point of view.

The process becomes more than just technical, it adds up political, ethnic and social determinants. The case of the denomination 'Bektashi' in Albanian censuses is an 
interesting study subject. Technically they are not a schism from Islam, but a special subgroup. The example of the Luther's ninety-five theses, Thesenanschlag as the beginning of reformation is a real schism. In year 1521 pope excommunicated Luther and the division still remains today. [25] Both groups define themselves as Christian and are represented as subcategories of Christianity. While the Bektashi order was suppressed in Turkey because of political reasons it changes its headquarters to Albania. [26] Not knowing their true identity follows in mistakes like the actual one where they can find themselves wrongly represented, with underrepresentation connotations and whole census results jeopardized on religion. The other extreme of underrepresentation can be the case of numbering the individual more than once. The example of the Japanese census where of Shintoists and Buddhists are counted more than once because they chose to follow practices and religious events of each other brings a total larger than the whole population. [16]

To conclude a general approach from the Islamic perspective as a starting point to improvement is needed. Many countries don't include questions about religion on their censuses, but this is not the case of Albania. Good results will not provoke friction between communities and none of them is contrary to census in principle. Islam itself from the beginning recommended a census in the words of the Prophet to record names of Muslims in Medina. Some pretentions would be contrary to oversimplify the question. Narrations from the Prophet show a different approach to ask about religion when s/he is dead. Questions consist on being asked by angels; "Who is your Lord?", "What is your religion?", "Who is this man who was sent among you?" "How did you know?" accompanied with the personal responses. [25] [26] But this is the special case of a big life event, the transition from one world to another and the goal of asking is quite different. The same would be in case of studying a pathological event. The dichotomous variable of a certain religious affiliation wouldn't predict the outcomes of some risk behavior. For example religious affiliation as Muslim when not followed from alcohol abstinence can't be a determinant in lowering the cardiac events caused by alcohol. [27] Thus the first option of just recording under self-declaration, as the first Muslims did in Medina following the orders of the Prophet would be enough for Muslims with a condition based in a famous Qur'anic verse 'There is no compulsion in the religion ..." Qur'an; 2:256 [28] This means the census population have to be counted in a climate of complete freedom to answer. This type of freedom can be easily understood in western countries of consolidated democracy but still is subject of doubt in ex-communist countries like Albania. Freedom doesn't consist just at the moment of fulfilling the questionnaire but first the citizen has to be confidant of the integrity and professionalism of the questionnaire compiler. Finding errors in questionnaire formulation can lead to withdrawal and refutation. 


\section{Conclusions}

Census geographical differences can be found in small countries like Albania too. Although they are real mistakes with representation effects are more likely to happen because the underrepresented minorities doesn't have a strong voice to correct errors or are unaware. In some cases they totally withdraw from participation especially when fear to answer is present. Religion is a sensitive topic but fortunately not of any risk related to interreligious communities' relationships or ethnic grounds in Albania. Political ground has to be monitored continuously because of the dictatorial past of the country and the fragile democratic institutions. Census 2011 results in religion and the expected next census face in these frameworks difficulties which are mostly but not entirely technical. Data from the last census brought the technical question about the nomination 'Bektashi' as a different category from 'Islam'. Separations from the original body happen with the goal of diversification or the preservation of originality. The peculiarity of sub-divisions in relation to monotheistic beliefs is that it excludes the possibility of diversification, whether true or not, that the purpose of the ramification is to save the original message from corruption. Placing a sub-division with the name 'Bektashi' in a questionnaire where the other name is 'Muslim' constitutes a technical error and also makes a paradox with any objective that their community may have. Map shows a clear superposition of the non-respondents group with Bektashi affiliation. Problems could be larger than this which we don't have actually the possibility to access the whole of the database. Prompt action is needed for correction and clear methodology has to be in place for further counts.

\section{Bibliography}

[1] Durham ME. Twenty years of Balkan tangle. London: Allen \& Unwin; 1920. 28-29

[2] Çelebi E. An Ottoman Traveller: Selections from the Book of Travels of Evliya Çelebi, trans. Robert Dankoff and Sooyong Kim (London: Eland, 2010). 2011. 173-178

[3] Melady, T. P. (2013). Albania: a nation of unique inter-religious tolerance and steadfast aspirations for EU integration. 2013. Academicus International Scientific Journal, 12-17.

[4] Enquête dans les Balkans, Paris, Centre Européen de la Dotation Carnegie, 1914. Frankfurt am Main: Textor Verlag; 2008.

[5] Cleenewerck L. His Broken Body: Understanding and Healing the Schism between the Roman Catholic and Eastern Orthodox Churches. Euclid University Press; 2007.

[6] [Internet]. Shtetiweb.org. 2020 [cited 2 April 2020]. Available from: http:// shtetiweb.org/wp-content/uploads/2015/10/Kushtetuta-e-Republikes-Socialiste-teShqiperise-1976.pdf 
[7] Diaspora e Shqipërisë në Shifra, 2019. 1st ed. Tirana: INSTAT Albania; 2019. 13-14

[8] Europe: Albania - The World Factbook - Central Intelligence Agency [Internet]. Cia.gov. 2020 [cited 1 April 2020]. Available from: https://www.cia.gov/library/ publications/the-world-factbook/geos/al.html

[9] Zani i Naltë - 9 - 1938: Nji lutje Kryegjyshatës së hirëshme. (2015). Tiranë: Komuniteti Mysliman Shqiptar. 32 (148) (151) (180)

[10] Instatgis.gov.al. (2019). Instat - Web Atlas. [online] Available at: https://instatgis. gov.al/\#!///prefectures/population/prefpop1 [Accessed 24 Sep. 2019].

[11] Popullsia sipas religjionit 1923-2011 [Internet]. Open.data.al. 2020 [cited 2 April 2020]. Available from: http://open.data.al/sq/lajme/lajm/lang/sq/id/670/Popullsiasipas-religjionit-1923-2011

[12] Census of Population and Housing 2020 in Albania [Internet]. Instat.gov.al. 2020 [cited 7 April 2020]. Available from: http://www.instat.gov.al/media/4319/noncore. pdf

[15] Bass F. Guide to the Census,+ Website. John Wiley \& Sons; 2013. 4-6-10-32-6389-103-125

[14] Glaese J. United in diversity? Religious categorization in the German 2011 census. Ethnic and Racial Studies. 2019;:1-20.

[15] Musaraj, A. Intercultural and Interreligious Communication in the Balkan. 2013. Academicus International Scientific Journal, 36-43.

[16] Facts IS. Alessandro Ferrari-Silvio Ferrari Religion and the secular State: the Italian case. Cardozo Electronic Law Bulletin. 2010;16:1.

[17] Brancatello A, Ciardelli L, Osti S, Succi R, Attili M, laccarino C. II processo produttivo delle statistiche demografiche: le procedure e i controlli di qualità. ISTAT. 2010;4/2010. [16] L'Istituto nazionale di statistica (Istat). Appartenenza e pratica religiosa tra i cittadini stranieri [Internet]. Istat.it. 2019 [cited 17 July 2019]. Available from: https:// www.istat.it/it/archivio/169710

[17] Good D. Questions on religion in the United States Census. Population Index. 1959 Jan 1:3-16.

[18] Thorvaldsen G. Religion in the Census. Social Science History. 2014;38(1-2):20320.

[19] Kosmin BA, Keysar A, Cragun R, Navarro-Rivera J. American nones: The profile of the no religion population, a report based on the American religious identification survey 2008.

[20] Audretsch DB, Boente W, Tamvada JP. Religion, social class, and entrepreneurial choice. Journal of Business Venturing. 2013 Nov 1;28(6):774-89. 
[21] Macioti, I, Musaraj, A. Albania and the teaching of religion in schools. 2017. Academicus International Scientific Journal; 14-27

[22] Wolffe J. Elite and Popular Religion in the Religious Census of 30 March 1851. Studies in Church History. 2006;42:360-71.

[23] Marshall P. 1517: Martin Luther and the Invention of the Reformation. Oxford University Press; 2017 Jul 25. 54

[24] Birge JK. The Bektashi order of dervishes. Luzac; 1937. 85

[25] Abū Dā’ūdSulaymān ibn al-Ash‘athal-Sijistānī, Za'ī A, Qāộ̄ Y, Abū Khalīl. English translation of Sunan Abu Dawud. Volume 5. Riyadh: Darussalam; 2008. 240-242

[26] Tirmidhī M, Abū Khalīl., Za'ī A. English translation of Jāmi' at-Tirmidhī. Volume 2. Riyadh: Darussalam; 2007. 443-444

[27] Akshija I. Ischemic Heart Disease Correlates with Muslim Names in a Population of Ten Year First Admissions at Tirana University Hospital Center. InpHealth 2019: Proceedings of the 16th International Conference on Wearable Micro and Nano Technologies for Personalized Health 10-12 June 2019, Genoa, Italy 2019 May 29 (Vol. 261, p. 294). IOS Press.

[28] [Internet]. 2020 [cited 9 April 2020]. Available from: https://quran.com/2/256 